\title{
Neonatal pressure ulcers: prevention and treatment
}

\author{
This article was published in the following Dove Press journal: \\ Research and Reports in Neonatology \\ 14 September 2017 \\ Number of times this article has been viewed
}

\author{
Pablo García-Molina ${ }^{1,2}$ \\ Alba Alfaro-López' \\ Sara María \\ García-Rodríguez' \\ Celia Brotons-Payál \\ Mari Carmen \\ Rodríguez-Dolz ${ }^{1,2}$ \\ Evelin Balaguer-López ${ }^{1,2}$ \\ 'Department of Nursing, University of \\ Valencia, ${ }^{2}$ Research Group of Pediatric \\ Nutrition, INCLIVA Foundation, \\ Valencia, Spain
}

\begin{abstract}
Health professionals should be prepared to respond to the needs of hospitalized neonates. The health team must consider multiple situations, where the neonate is at risk of having an adverse effect. One of the main interventions that health professionals must practice when interacting with hospitalized newborns is skin care. Neonates often suffer from diaper rash or intravenous drugs extravasation. Recently, hospitalized neonates and especially those in an unstable clinical situation are also at a risk of developing pressure ulcers. The presence of a pressure ulcer in a neonate can lead to serious problems to survival (eg, sepsis, clinical instability). This is the reason why, with this literature review, we attempt to answer questions from health professionals caring for neonates about the prevention and treatment of pressure ulcers. Keywords: infant, pressure ulcer, treatment, prevention, wound, assessment
\end{abstract}

\section{Introduction}

Until recently, the pediatric and neonatal populations were not considered to be at risk of pressure ulcers (PUs). They were considered to be free from PUs, since these were associated with adults. Newborns (NB) were not considered at risk of developing PUs due to the relative ease of being repositioned by health professionals. Thus, the development of PUs in hospitalized neonates was attributed to specific causes of therapeutic interventions, considering this adverse effect as unavoidable. ${ }^{1,2}$ Nevertheless, there is now an emerging awareness that acute and immobilized patients, including neonates, are at risk of developing PUs. Most of the prevention and treatment protocols available for neonatal population are based on adult clinical practice, regardless of the anatomical and physiological difference between adults and neonates. ${ }^{3}$ It is necessary to implement preventive and treatment measures adapted to the neonatal age. But first, we must explain which characteristics make NBs vulnerable to the presence of PUs.

\section{Skin characteristics of premature and healthy NBs}

After delivery, the skin of the term NB infants faces an environment very different to where it was developed. The skin is the first barrier that communicates with the dry, hard and pathogenic microorganisms-loaded external environment. It is the main organ that provides thermoregulation, immunity, and protection against dehydration and mechanical protection. ${ }^{4}$

When a term NB is born, the first substance that covers the skin is vernix caseosa. This substance is made of antimicrobial peptides, sebaceous secretions, corneal cells and lanugo hairs which provide a high moisturizing power (it protects against insensible
Correspondence: Pablo García-Molina Department of Nursing, University of Valencia, C/ Jaume Roig, s/n, 46010

Valencia, Spain

Tel +34963864182

Fax +34963983035

Email pagarmo3@uv.es 
water losses) as well as protection against the new colonization of the skin of the NBs. ${ }^{5}$ Depending on the gestational age (GA) at birth, there will be more or less vernix caseosa. For example, a post-term infant will have absorbed most of the vernix caseosa into the womb. That is why preterm and post-term NBs will not have that primary protection layer. ${ }^{6,7}$

The skin of a term NB is not considered mature until 3 weeks have passed; a preterm NB (PTNB) requires even longer time. ${ }^{8}$ All normal skin functions are altered in the PTNBs: protection against trauma or pressure, protection against ultraviolet rays, protection against infection, thermoregulation control and skin permeability. It is necessary to focus care on restoring the normal functions of the skin or alleviating its immaturity until the NB skin is completely developed. ${ }^{9}$

\section{Neonatal PUs}

The definition of PUs is given by research on adults. Currently, the international consensus continues to work on a definition for PUs, which evolves with new investigations and reviews. In 2014, the National Pressure Ulcer Advisory Panel (NPUAP), the European Pressure Ulcer Advisory Panel (EPUAP) and Pan Pacific Pressure Injury Alliance (PPPIA) recommended the following definition: "A pressure ulcer is localized injury to the skin and/or underlying tissue usually over a bony prominence, as a result of pressure, or pressure in combination with shear. A number of contributing or confounding factors are also associated with pressure ulcers; the significance of these factors is yet to be elucidated."10

Other organizations have adopted similar definitions but with some modifications. Thanks to the new model created by García-Fernández et al, ${ }^{11}$ a PU is considered as a dependence-related injury. Thus, the National Group for the Study and Assessment of Pressure Ulcers (GNEAUPP) $)^{10,12}$ suggested in 2014 the following definition: "A pressure ulcer is a localized lesion on the skin and/or the underlying tissue, over a bony prominence, as a result of pressure, or pressure in combination with shear forces. Occasionally, they may also appear on soft tissues subjected to external pressure by different materials or clinical devices."

\section{PU etiology}

The developmental mechanism of a PU is based on the poor blood supply to the tissue produced by a continuous pressure on an area. ${ }^{13-15}$ This pressure triggers occlusion of blood capillaries causing ischemia. Regarding the amount of pressure required for the capillary occlusion, and consequently for damaging the capillary, there is no consensus among different authors and investigations. Most studies show that pressure maintained over time and its intensity are directly proportional to the injury risk. ${ }^{12,13}$ In addition, it is known that other factors such as direction of pressure forces (friction and shear), as well as microclimate of the area, can increase the risk of tissue damage. ${ }^{12}$

\section{PU classification}

The international PU classification by the NPUAP/EPUAP/ PPPIA describes four categories. ${ }^{10}$ As for category I, a nonblanching erythema is produced on intact skin; in category II, there is a partial loss of skin thickness or blisters may appear; in category III, there is a total loss of skin thickness; and in category IV, there is total loss of tissue thickness, with exposed muscle or bone. Besides these four categories, the NPUAP describes two additional categories: the fifth category is the "unclassifiable", in which there is total loss of the skin or tissue thickness, and depth is unknown; The sixth category is the "suspected deep tissue injury", with unknown depth. ${ }^{10}$

\section{Neonatal risk factors and most frequent locations}

Risk factors for pediatric and neonatal populations are similar to those for adults admitted to critical units. Although, due to the characteristics of neonatal patients, there are risk factors with greater strength related to the development of PUs. The main risk factors at neonatal age are the use of therapeutic and diagnostic devices (50-90\% of the PUs in neonates), ${ }^{3,16}$ presence of endotracheal tube, use of noninvasive mechanical ventilation, hypotension and hypoxemia, prolonged stay in the neonatal intensive care unit (NICU), low birth weight $\left(<2500\right.$ g) and prematurity $\left(<37\right.$ weeks of GA) ${ }^{16-21}$

The most frequent locations of PUs in neonates are the occipital region and ears, ${ }^{22-24}$ as well as anatomical areas where therapeutic or diagnostic systems are at risk, such as fingers and feet (pulse oximetry sensor), skin support areas (vascular catheters), thorax (electrodes), ear lobe (capnaptic clamp sensor), nasal septum, back of the neck, nostrils and cheeks (continuous positive airway pressure interface, both binaural cannulae and face mask). ${ }^{20,23,25}$

\section{Epidemiology}

The scientific literature reveals a worldwide PU incidence ranging from 3.70 to $21.60 \%$ in the NICUs, with a prevalence of 23\% ${ }^{3,16,17,25-27}$ These data highlight the need to apply measures to prevent and treat PUs, especially in NBs, with clinical devices admitted to the NICU. 
Due to the high incidence and prevalence of PUs in neonatal population as demonstrated in the literature and lack of studies dealing with prevention and treatment of PUs, our research team has performed a critical review of the literature to explain the preventive and treatment measures that may be used for PUs in the neonatal population.

\section{Methods}

We performed a narrative and critical review of the literature. We searched for articles related to PUs using a series of keywords. We selected those articles published up to 20 years ago, in Spanish or English language, and those that included the neonatal population.

Our study attempts to answer the following questions:

1. Which preventive measures for PUs have been investigated in the neonatal population in the last 20 years?

2. Which PU treatments can be used safely for neonates?

We searched the MEDLINE (through PubMed) with a research strategy shown in Table 1.

In parallel, as studies were included according to the criteria, manual searching was carried out on the bibliographic references from the registers included to detect relevant documents with the research question and that were not identified in the bibliographic search. For the manual search, it was taken into account that one of the authors of this article belongs to the Advisory Committee of the GNEAUPP and is Editor of the UPPPEDIATRIA.org web, having at his disposal the main investigations carried out on PUs in neonates. Among the main documents taken into account, there were the Clinical Practice Guidelines of the EPUAP, NPUAP and PPPIA, as well as the guidelines of the National Institute for Health and Care Excellence (NICE) or the clinical practice guidelines of the Sanitary Department of the Valencian Community (Spain).

Once all the documents were recovered, a selection process was carried out according to the eligibility criteria. Two members of the team reviewed independently the title and abstract for the inclusion of an article in the review. They used a register paper created for that end. If there was divergence, a third reviewer, blinded to the evaluations, settled if the article was accurate for the review. The final documents were distributed to the members of the research team, and the most relevant information on treatment and prevention of PUs in the neonatal population was extracted.

\section{Results}

\section{Prevention}

Preventive interventions in the neonatal population are based on four aspects: risk assessment, skin care, nutrition and pressure management.

Pressure Ulcer Risk Assessment Scales (PURAS): skin assessment and pressure ulcer risk rating scales

So far, only studies have been published on 14 scales used for the evaluation of PU risk in pediatric population. Of these, only four of these PURAS - Braden Q, Glamorgan Scale, Starkid and Neonatal Skin Risk Assessment Scale (NSRAS) - have been used in the neonatal population. ${ }^{28-31}$ The limited number of validated scales has to be added to the fact that the majority of scales used in the pediatric and neonatal population are adaptations of the adult scales and do not differentiate between a child or a neonate. Only one validated scale, Glamorgan Scale, was designed for pediatric population (neonates and children). ${ }^{32}$ This scale has been extensively studied and compared with other scales such

Table I PubMed search strategy

\begin{tabular}{|c|c|}
\hline Search & Query \\
\hline$\# 1$ & $\begin{array}{l}\text { ((skin [Title/Abstract] AND breakdown [Title/Abstract]) OR (ulcer*[Title/Abstract] OR wound*[Title/Abstract] OR erythema [Title/ } \\
\text { Abstract] OR sore*[Title/Abstract] OR injur*[Title/Abstract]) AND (pressure [MeSH Terms] OR pressure [Title/Abstract] OR } \\
\text { decubit*[Title/Abstract])) OR (pressure ulcer [MeSH Terms] OR bedsore*[Title/Abstract])) }\end{array}$ \\
\hline$\# 2$ & $\begin{array}{l}\text { ((prevention*[Title/Abstract] OR precaution*[Title/Abstract] OR prophy/*[Title/Abstract] OR "prevention and control” [MeSH } \\
\text { Subheading]) OR ((reduc*[Title/Abstract] OR decreas*[Title/Abstract] OR diminution*[Title/Abstract] OR less*[Title/Abstract]) AND } \\
\text { (incidence [MeSH Terms] OR incidence*[Title/Abstract] OR frequency [Title/Abstract] OR rate [Title/Abstract] OR occurrence } \\
{[\text { [Title/Abstract]))) }}\end{array}$ \\
\hline$\# 3$ & $\begin{array}{l}\text { (treatment*[Title/Abstract] OR intervention*[Title/Abstract] OR cure*[Title/Abstract] OR “cicatrization" OR (healing*[Title/ } \\
\text { Abstract] OR decreas*[Title/Abstract] OR diminution*[Title/Abstract] OR less*[Title/Abstract])) }\end{array}$ \\
\hline$\# 4$ & $\begin{array}{l}\text { (child [MeSH Terms] OR child*[Title/Abstract] OR “child, preschool” [MeSH Terms] OR infant [MeSH Terms] OR infant*[Title/ } \\
\text { Abstract] OR “infant, newborn" [MeSH Terms] OR neonate*[Title/Abstract] OR kid*[Title/Abstract] OR newborn*[Title/ } \\
\text { Abstract] OR baby [Title/Abstract] OR babies [Title/Abstract] OR teenager*[Title/Abstract] OR adolescent [MeSH Terms] OR } \\
\text { adolescen*[Title/Abstract] OR pediatric*[Title/Abstract] OR neonatal [Title/Abstract]) }\end{array}$ \\
\hline$\# 5$ & $\#$ I AND \#2 AND \#3 AND \#4 \\
\hline
\end{tabular}


as Braden Q, showing good clinicometric values. ${ }^{33,34}$ Some authors state that risk scales are not useful for reducing PUs and that their data are biased by the use of preventive measures. ${ }^{35}$ However, these authors do not take into account the usefulness of these scales in the management of PUs, as well as in the training of health professionals in prevention of PUs. ${ }^{30,36}$ At present, there is only one risk assessment scale that is exclusively addressed to the neonatal population and has undergone two validation studies, the NSRAS scale. ${ }^{37,38}$ Similar to the Braden Q scale, the NSRAS reflects the physical and developmental needs of a neonatal patient and consists of six mutually exclusive subscales (General Physical Condition, Activity, Mobility, Nutrition, Moisture, Mental State), the scores of which range from 1 to 4 . Similarly to the Braden Q, a low score indicates a high risk. The validity and reliability of the NSRAS was tested in a group of 32 NBs admitted to the NICU, resulting in low interobserver reliability in three of the subscales (Mental State, Mobility and Moisture). In 2015, another research team carried out the cross-cultural adaptation of the scale and validation process on a neonatal population of almost 600 neonates, noting that the Spanish version e-NSRAS is a valid and reliable scale to be used in the hospitalized neonatal population.

In addition to risk assessment scales, direct assessment by professionals is also basic to the detection of PUs. According to the literature, the main recommendations are based on a complete and documented examination of the skin, in which, in addition to assessing skin condition at the time of examination, the risk of PUs is determined by a validated scale. ${ }^{39}$ This examination must be done on admission and every 12 or 24 hours, ${ }^{40}$ assessing from head to foot, putting special interest in high-risk areas. ${ }^{3}$ The Preventive Care Guidelines of the NICE advise that in assessing the skin of NBs, special attention should be paid to changes in the skin of the occipital area, temperature and the presence of erythema or blanching areas. ${ }^{31,39,41}$

The contact area between the skin and the therapeutic and diagnostic devices should be monitored several times a day or even hourly in neonates at risk of suffering from PUs. ${ }^{10,24,42}$

Daily, general and exhaustive inspection of the skin can be performed while cleaning the NBs or while manipulating the neonates during diaper change occurs or while performing another therapeutic or diagnostic technique. ${ }^{24,39}$ We will never disturb the newborn just to assess the skin, because development centered care practice suggests that techniques of minimal manipulation are performed. That is, health professionals must perform all the techniques in a single manipulation and let the neonate rest between manipulation and another. In this way, the rest periods and tranquility of the NBs can be increased, thus facilitating their cognitive and psychomotor development. ${ }^{43}$

\section{Skin care depending on GA}

\section{Skin hygiene and hydration}

During the first 2 weeks, skin hygiene is not recommended on a daily basis. Skin cleaning should only be done with warm water and cotton compresses or a soft material. ${ }^{44,45}$ The use of alkaline and antiseptic soaps should be avoided in preterm or low-birth-weight infants, and if used, they should be rinsed out properly..$^{40,46,47}$ The use of soaps and creams of neutral $\mathrm{pH}$, without preservatives, perfumes or coloring agents, should be evaluated for the safety of term infants (over 48 hours of life) or preterm infants (after 2 weeks, when the maturation of the PTNB skin occurs). ${ }^{46,48}$

It is advisable to hydrate the skin of NBs at risk for PUs (at term, after the first 48 hours) using emollients (oils, emulsion, milk) containing hyperoxygenated fatty acids, applied at individual dosages, to reduce both frequency and the severity of the PUs. ${ }^{24,44,45,49-51}$ In preterm infants, no ointment or topical cream or mineral oils should be used as a usual form of skin moisturizing due to the risk of contamination by coagulasenegative Staphylococcus or any bacteria, fungus or virus that causes nosocomial infection. ${ }^{52}$

In term NBs, vernix caseosa has higher water content and biomechanical defense properties than any cream, ointment or moisturizing solution. Therefore, it should not be removed until the first 48 hours of life or when the amount of vernix is low. ${ }^{5,53}$

\section{Control and management of humidity}

Excess moisture in the skin of the newborn should be avoided, as it favors the formation of PUs or moisture ulcers. ${ }^{3,44,54-57}$ It is necessary to take into account that infants are mixed incontinents, both of feces and of urine, and both substances can macerate the skin facilitating the appearance of PUs. ${ }^{31}$ Other factors that increase skin moisture, raising the risk of PUs, should also be considered. Some of these factors are the presence of ostomies or drainage, excess regurgitation or sialorrhea and the presence of noninvasive mechanical ventilation with heated and humidified systems (especially those systems that condense the water in the tubes). ${ }^{57-66}$

The main nursing care practices that can reduce humidity and therefore the PU risk are changing diapers, cleaning and drying the area after each episode of incontinence, ${ }^{67}$ applying absorbent dressings between the devices and the skin according to the needs of absorption (polyurethane, alginate, hydrocolloid fibers), ${ }^{62}$ and/or using barrier products tested in neonatal patients (creams, lotions, pastes and/or emollients enriched with zinc oxide, polyurethane spreads, molding pastes, silicones). ${ }^{40,44,55}$ 


\section{Nutrition}

Nutritional control is necessary because low birth weight, weight loss after 4-5 days of birth, malnutrition and dehydration may contribute to the development of PUs in NBs. ${ }^{3,31,45,68,69}$ It is recommended to evaluate the nutritional status in children with high risk of PUs or with presence of PUs using parameters such as weight, weight/height, cranial perimeter, body mass index and cutaneous folds in relation to GA. ${ }^{38,70}$

The energy expenditure of growth and the pathological process must be balanced by an adequate supply of nutrients. Therefore, it is necessary to measure fluids, proteins and calories based on anthropometric and clinical characteristics. ${ }^{71,72}$

Parenteral or enteral nutrition should be started as soon as possible for neonatal patients at risk of malnutrition for the prevention of PUs. ${ }^{39,73,74}$ However, breastfeeding should always be promoted through suckling, feeding bottle or enteral catheter. ${ }^{71}$

\section{Pressure management}

Local pressure relief devices

Local pressure relief devices are preferred for the prevention of secondary PUs to the use of therapeutic and diagnostic devices. Preventive interventions are shown in Tables 2 and 3.

At the occipital region, pressure relief devices such as gel or water, polyurethane and/or viscoelastic devices are also used..$^{31,81-83}$ The use of hydrocolloid dressings is not recommended for redistribution of pressure, as they protect against friction but not against shear or direct pressure. ${ }^{24}$

\section{Postural changes}

The frequency of postural changes will be chosen depending on the PU risk evaluated using a validated risk scale, tolerance of the neonate to the manipulation, the presence or absence of PUs and the clinical stability of the neonate..$^{24,39,71,84}$ Attempts should be made to combine all interventions (including postural changes) when NB is manipulated. ${ }^{31}$

NBs at risk for PU, that cannot be mobilized on their own and are not on a special surface for pressure management (SSPM), should be mobilized at least every 2 hours, as long as their clinical state allows it and accepts the manipulations that lead to change without being clinically altered. $3,38,39,85,86$ NBs over a high-performance support surface (static or dynamic) can be mobilized every 4 hours..$^{87,88}$

\section{Special surfaces for pressure management}

Adult mattresses or SSPMs must not be used for neonates, as they are not suitable for their special morphology. ${ }^{38,84,89}$

The assignment of SSPMs should be protocolized to avoid their misuse (especially those with higher technology) and allow them to be assigned according to age, risk, body surface area, presence or absence of PUs, PU severity and baseline pathology of neonates..$^{83,88,90,91}$

Table 2 PU preventive interventions for therapheutic clinical devices.

\begin{tabular}{ll}
\hline Therapeutic devices & Interventions \\
\hline NIMV: interface use. & Remove the treatment when possibly. ${ }^{26}$ \\
& Apply dressing or gel device that redistributes pressure. ${ }^{18,59,65,75}$ \\
& Leave a half-hour break between 4 to 6 hours of treatment. ${ }^{76}$ \\
& Alternate nasal prongs with nasal mask..$^{21,59,77}$ \\
Endotracheal tube & Do not attach with adhesive tape directly to the NB skin. Use adding devices in bridging form. ${ }^{45}$ \\
Drains and colostomies, ileostomy, nephrostomy & Change the pressure points of devices. ${ }^{62,78}$ \\
Venous catheters & Apply dressings between skin and device. ${ }^{3}$ \\
Nasogastric tube, urinary catheter & Mobilize the catheter and nasogastric tube at list once a day. ${ }^{78}$ \\
Ostomy (gastro, trachea) & Mobilize the gastric device to avoid pressure at the same points. \\
& Resizing the gastrostomy device when there is a clearance. ${ }^{62,79}$ \\
\hline
\end{tabular}

Abbreviations: PU, pressure ulcer; NIMV, noninvasive mechanical ventilation; NB, newborn.

Table 3 PU preventive interventions for diagnostic clinical devices.

\begin{tabular}{|c|c|}
\hline Diagnostical devices & Interventions \\
\hline \multirow[t]{3}{*}{ Pulse oximetry sensor } & Change the site sensor frequently (from 2 to 4 hours depending on risk). ${ }^{42,78}$ \\
\hline & Do not hold the sensor with flexible tape. ${ }^{42,80}$ \\
\hline & Do not force the tape over the sensor. ${ }^{42,80}$ \\
\hline Capnography sensor & Change location every 4 hours and monitor the sensor temperature. ${ }^{23,78}$ \\
\hline Electrocardiogram electrode & Place on the back when the patient is prone. ${ }^{76}$ \\
\hline Temperature sensors & Change position every 3 or 4 hours. $^{78}$ \\
\hline
\end{tabular}

Abbreviation: PU, pressure ulcer. 
Static polyurethane foam surfaces (only a mattress or in combination with a head prevention device) have been shown to have a better cost-effectiveness ratio than dynamic SSPMs with low pressure constant. ${ }^{89}$ However, recent research has shown that certain reactive SSPMs (Figure 1) redistribute pressure better than static polyurethane surfaces. ${ }^{38}$

Despite the use of the latest generation of SSPMs, the occipital area must be highly protected compared to the other areas of the body. This zone is the one that maintains more pressure in children between the neonatal age and 2 years in all the mattresses studied. ${ }^{92-94}$

The viscoelastic and gel surfaces are equally effective in preventing PUs. However, the viscoelastic ones have a better circumference and biparietal index and maintain the temperature better. ${ }^{81,91}$

High-specification foam mattresses reduce pressure more than standard hospital mattresses and synthetic wool (lamb skin) surfaces. ${ }^{82,84}$

\section{Treatment}

The PU treatment in neonates should be applied taking into account the following four crucial factors: systemic absorption rate of the active ingredient or its excipients, potential cytotoxicity, hypersensitivity to any component and possible adverse reactions. The resources available for neonates are less compared to the pediatric or adult population. ${ }^{1,24,95-97}$ The choice of the treatment must depend on the GA, PU category and its location, risk of infection, skin type and pathology. ${ }^{24,98-100}$

\section{Category I}

It is necessary to differentiate between a category I PU and a blanching erythema (by means of digitopression or with a transparent disc). ${ }^{31}$ It is necessary to eliminate the source

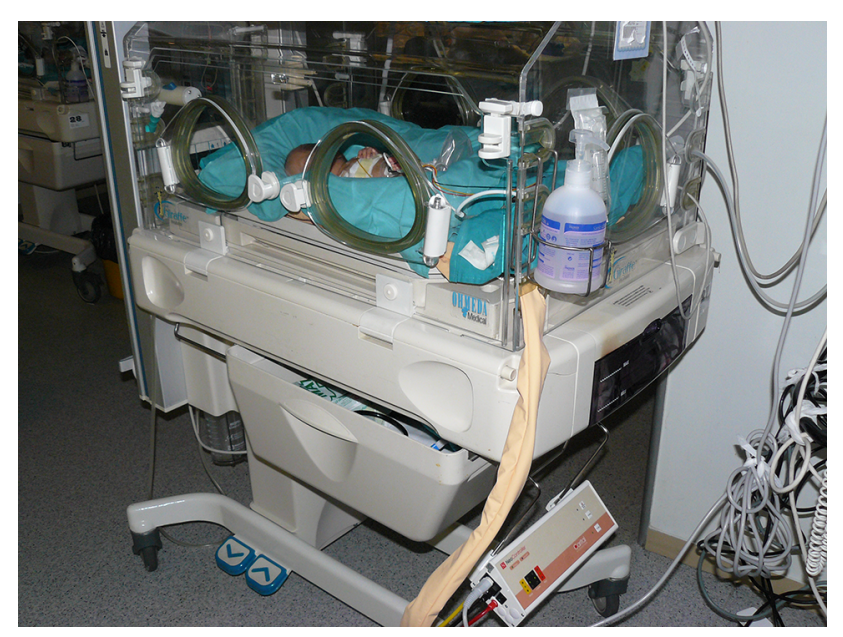

Figure I Reactive special surface for pressure management. of pressure on the skin and to apply emollients (ointments, oils or emulsions) only in the affected area, using approved products. Essential fatty acids should be used with caution, as their effectiveness is not proven. When applying any product to the skin of a PTNB $<32$ weeks of GA, its effect should be monitored during the first 24 hours..$^{24,101}$

If it is not possible to remove pressure from the area, it will be necessary to apply a foam dressing with low adhesiveness (silicone or polyacrylate base) or without adhesive. ${ }^{101,102}$ The diameter of the dressing used in neonates must exceed that of the injured area by $1 \mathrm{~cm} .{ }^{24,102}$

\section{Categories II, III and IV}

\section{Cleaning}

A PU should be cleaned by irrigating the bed and the edges of the wound with physiological saline or sterile water using a 10-20 $\mathrm{ml}$ syringe and with a $20 \mathrm{G}$ catheter (without needle). ${ }^{24,103}$ It is not advisable to use antiseptics for routine bed cleaning due to the risk of systemic absorption and potential cytotoxicity. ${ }^{104}$ Exceptionally, an antiseptic could be used only on the perilesional skin and if there is risk of bed contamination. After waiting for sufficient time to take effect, the antiseptic should be removed completely with physiological saline solution or with sterile water. ${ }^{24,39}$

\section{Debridement}

Different debridement techniques can be performed to remove necrotic tissue. Autolytic debridement is the most commonly used in neonates due to its innocuousness (eg, use of hydrogel in gel or dressing). ${ }^{3,24,39,105}$ It is preferable to shear (partial or total), mechanical or enzymatic debridement. Sharp debridement in neonates should be chosen according to the PU location. ${ }^{104} \mathrm{~A}$ partial sharp debridement can be executed by a registered nurse, while a total shearing will be performed by a surgeon. ${ }^{24}$ Enzymatic debridement is not recommended, but if it is carried out, the product must be approved; for example, collagenase (not an approved product) will be replaced by another type of debridement. ${ }^{51}$ For a category II PU, there are three intervention options: 1) keeping the blister and covering it with a dressing to avoid uncontrolled rupture; 2) puncturing the blister, draining the liquid and covering with a dressing to avoid a possible infection; 3) debriding the blister completely with scalpel and tweezers, and covering with a dressing. ${ }^{106}$

\section{Exudate management}

When there is excess of exudate in the PU, barrier products can be used on the perilesional skin. For those deep PUs with 
a large amount of exudate, polyurethane foam dressings are recommended, together with hydrocolloid hydrofiber. ${ }^{101}$ For superficial and slightly exudative PUs, porous silicone meshes covered by sterile gauze or tubular mesh can be used. ${ }^{106}$

\section{Bacterial colonization and infection management}

If there are signs of infection, it will be necessary to apply impregnated dressings with topical antiseptics (silver, polyhexamethylbiguanide) that are not contraindicated in neonates. ${ }^{24,107,108}$ When using silver, some authors recommend that an analytical control should be done within 2 weeks of being prescribed, followed by a resting period. ${ }^{109}$ The application of iodinated antiseptics is not recommended, which may favor the onset of hypothyroidism. Use of alcohols may cause irritation and necrosis. Topical antibiotics are associated with antimicrobial resistance and can cause adverse effects related to systemic absorption; ${ }^{24,96}$ specifically, neomycin may cause sensorineural deafness. Silver sulfadiazine should not be used in any format, as it can provoke argyria by systemic absorption, as well as kernicterus by the absorption of sulfadiazine. ${ }^{96,110}$

\section{Healing stimulation}

Cure dressings in a humid environment (hydrogel, hydrocolloid, hydrocellular polyurethane foam and transparent semipermeable dressings) are found to show better results in the healing time compared to traditional or dry (gauze) cures. ${ }^{24,39,69,96,111}$ The dressing choice depends on the healing phase. It is also recommended to use gauze previously moistened with saline or hydrogel. After the placement of the first cure dressing in a humid environment, the effect should be evaluated at $12-24$ hours observing the wound bed.$^{24}$ If gauze is used, it should be evaluated prior to its complete desiccation, that is, from 6 to 8 hours after placement, to avoid pain, erosion or trauma to the bed when it is removed. It is advisable to use silicone dressings and lipocolloid substances as they favor atraumatic removal. ${ }^{12,113}$ Calcium alginate dressings should be used with caution due to the systemic absorption of calcium and sodium. ${ }^{67}$ Combined dressings (hydrocolloid hydrofiber) and products with collagen should also be used with caution due to the risk of allergies and bleeding. There are fewer studies ${ }^{114}$ on the application of a barrier film between perilesional skin and adhesive dressing, although some authors do recommend it in infants older than 1 month. ${ }^{115,116}$

\section{Negative-pressure wound therapy (NPWT)}

NPWT is indicated for neonates with stage III or IV PUs, after appropriate debridement, if there is no osteomyelitis. The foam dressing is placed directly onto the wound base, and a continuous negative pressure is set at -50 to $-75 \mathrm{mmHg}$ for younger children. When using NPWT for neonatal PUs, there is a risk of formation of PUs due to pressure from the tubing system. Care must be taken to prevent further pressure when placing tubing for NPWT, particularly over bony prominences. ${ }^{117}$

\section{Conclusion}

PUs represent one of the most important iatrogenic lesions at hospital settings, which is why it is necessary to implement effective measures to resolve them. Despite the high incidence and prevalence of PUs in hospitalized neonates, no specific studies have been conducted in this population, and hence, the preventive and treatment recommendations are of low scientific evidence. Most of the recommendations are extrapolated from adult population studies and expert opinions. However, the anatomical and physiological characteristics of the neonates are different from the children and adults, and so the measures must be adapted to the neonatal population.

The treatment approach to PUs should be carried out in an interdisciplinary way, in which the nursing professionals should have a leading role, since PU prevention and application of treatment in the hospital setting is their responsibility.

PU prevention in neonates focuses on skin care (hygiene and hydration, moisture control and management), pressure management (local pressure relief devices, postural changes and SSPMs) as well as adequate nutrition. However, a fundamental part is the assessment of PU risk by valuation scales. The scales validated for PU risk detection in neonates are scarce, and are adapted from adult scales. This impairs the adequate assessment in neonates, and highlights the need to develop scales applicable in neonates of all GAs.

Only a few products are approved for PU treatment in neonates. The risk of systemic absorption, toxicity, hypersensitivity and possible adverse reactions that can occur in neonates due to the application of products designed for adults limit treatment options. Hence, it is necessary to use authorized products.

Further research is needed on both prevention and treatment of PUs, to determine which interventions and products should be used. Randomized clinical trials in different units of neonatal hospitalization may provide consistent results. Care should be standardized for the prevention and treatment of PUs that may reduce the incidence and severity of these in hospitalized neonates.

\section{Disclosure}

The authors report no conflicts of interest in this work. 


\section{References}

1. Grupo de trabajo de la Guía de Práctica Clínica. Guía de Práctica Clínica para el Cuidado de Personas con Úlceras por Presión o Riesgo de Padecerlas [Clinical Practice Guide for the Care of People with Pressure or Risk Ulcers of Suffering]. Valencia: Conselleria Sanitat Comunidad Valenciana; 2012. Spanish.

2. August DL, Edmonds L, Brown DK, Murphy M, Kandasamy Y. Pressure injuries to the skin in a neonatal unit: fact or fiction. J Neonatal Nurs. 2014;20(3):129-137.

3. Baharestani MM, Ratliff CR. Pressure ulcers in neonates and children: an NPUAP white paper. Adv Skin Wound Care. 2007;20(4):208, 210, 212, 214, 216, 218-220.

4. Chiou YB, Blume-Peytavi U. Stratum corneum maturation. A review of neonatal skin function. Skin Pharmacol Physiol. 2004;17(2):57-66.

5. Tansirikongkol A, Hoath SB, Pickens WL, Visscher MO, Wickett RR. Equilibrium water content in native vernix and its cellular component. J Pharm Sci. 2008;97(2):985-994.

6. Irving V. Principles of neonatal skin care. In: White R, Denyer J, editors. Paediatric Skin and Wound Care. Aberdeend: Wounds UK; 2006:15-19.

7. Hardman M. In utero skin development. In: White R, Denyer J, editors. Paediatric Skin and Wound Care. Aberdeen: Wounds UK; 2006:1-19.

8. Loomis CA, Koss T, Chu D. Desarrollo de la piel fetal [Fetal skin development]. In: Frieden IJ, Esterly NB, editors. Dermatología Neonatal. 2nd ed. Barcelona: Elsevier España; 2009:1-17. Spanish.

9. Gilliam AE, Williams ML. La piel del lactante prematuro [The skin of the premature infant]. In: Frieden IJ, Esterly NB, editors. Dermatología Neonatal. 2nd ed. Barcelona: Elsevier España; 2009:45-57. Spanish.

10. National Pressure Ulcer Advisory Panel, European Pressure Ulcer Advisory Panel, Pan Pacific Pressure Injury Alliance. Prevention and Treatment of Pressure Ulcers: Quick Reference Guide. 2nd ed. Haesler E, editor. Perth: Cambridge Media; 2014.

11. García-Fernández FP, Agreda JJ, Verdú J, Pancorbo-Hidalgo PL. A new theoretical model for the development of pressure ulcers and other dependence-related lesions. J Nurs Scholarsh. 2014;46(1):28-38.

12. García-Fernández FP, Soldevilla-Ágreda JJ, Pancorbo-Hidalgo PL, Verdú Soriano J, López-Casanova P, Rodríguez-Palma M. Clasificacióncategorización de las lesiones relacionadas con la dependencia [Classification-categorization of dependence-related injuries]. Serie Documentos Técnicos GNEAUPP n ${ }^{\circ}$ II. Logroño: GNEAUPP; 2014. Spanish.

13. Orsted H, Ohura T, Harding K. Pressure, shear, friction and microclimate in context. In: International Review. Pressure Ulcer Prevention: Pressure, Shear, Friction and Microclimate in Context. A Consensus Document. London: Wounds International; 2010.

14. Razmus I, Lewis L, Wilson D. Pressure ulcer development in infants: state of the science. J Healthc Qual. 2008;30(5):36-42.

15. Ligi I, Arnaud F, Jouve E, Tardieu S, Sambuc R, Simeoni U. Iatrogenic events in admitted neonates: a prospective cohort study. Lancet. 2008;371(9610):404-410.

16. Bonell-Pons L, García-Molina P, Balaguer-López E, Montal ÁM, Rodríguez MC. Neonatal facial pressure ulcers related to noninvasive ventilation: incidence and risk factors. EWMA J. 2014;14(2):33.

17. Fujii K, Sugama J, Okuwa M, Sanada H, Mizokami Y. Incidence and risk factors of pressure ulcers in seven neonatal intensive care units in Japan: a multisite prospective cohort study. Int Wound J. 2010;7(5):323-328.

18. Günlemez A, Isken T, Gökalp AS, Türker G, Arisoy EA. Effect of silicon gel sheeting in nasal injury associated with nasal CPAP in preterm infants. Indian Pediatr. 2010;47(3):265-267.

19. Sardesai SR, Kornacka MK, Walas W, Ramanathan R. Iatrogenic skin injury in the neonatal intensive care unit. J Matern Fetal Neonatal Med. 2011;24(2):197-203.

20. De Paoli AG, Davis PG, Faber B, Morley CJ. Devices and pressure sources for administration of nasal continuous positive airway pressure (NCPAP) in preterm neonates. Cochrane Database Syst Rev. 2002;(4):CD002977.
21. Mazzella M, Bellini C, Calevo MG, et al. A randomised control study comparing the Infant Flow Driver with nasal continuous positive airway pressure in preterm infants. Arch Dis Child Fetal Neonatal Ed. 2001;85(2):F86-F90.

22. Manning MJ, Gauvreau K, Curley MA. Factors associated with occipital pressure ulcers in hospitalized infants and children. Am J Crit Care. 2015;24(4):342-348.

23. García-Molina P. Dispositivos terapéuticos como causa de upp y otras lesiones en pediatría [Therapeutic devices as a cause of UPP and other injuries in pediatrics]. Presented at: VIII Simposium Grupo Nacional de Estudio y Asesoramiento de Úlceras por Presión y otras Heridas Crónicas; November 10-12, 2010; Santiago de Compostela. Spanish.

24. Grupo de trabajo de la Guía de Práctica Clínica. Guía de prevención y tratamiento de UPP en pediatría [Guide for prevention and treatment of pediatric UPP]. In: Guía de Práctica Clínica para el Cuidado de Personas con Úlceras por Presión o Riesgo de Padecerlas. Valencia: Generalitat Valenciana, Conselleria de Sanitat; 2012:129-146. Spanish.

25. Fischer C, Bertelle V, Hohlfeld J, Forcada-Guex M, Stadelmann-Diaw C, Tolsa JF. Nasal trauma due to continuous positive airway pressure in neonates. Arch Dis Child Fetal Neonatal Ed. 2010;95(6):F447-F451.

26. Yong SC, Chen SJ, Boo NY. Incidence of nasal trauma associated with nasal prong versus nasal mask during continuous positive airway pressure treatment in very low birthweight infants: a randomised control study. Arch Dis Child Fetal Neonatal Ed. 2005;90(6):F480-F483.

27. Kottner J, Wilborn D, Dassen T. Frequency of pressure ulcers in the paediatric population: a literature review and new empirical data. Int J Nurs Stud. 2010;47(10):1330-1340.

28. Ness MJ, Davis DM, Carey WA. Neonatal skin care: a concise review. Int J Dermatol. 2013;52(1):14-22.

29. Garcia-Molina P, Balaguer-Lopez E. The risk assessment scales are an efficient tool in the prevention of pressure ulcers in hospitalized neonates. J Neonatal Biol. 2014;3:151

30. García-Fernández FP, Pancorbo-Hidalgo PL, Soldevilla Agreda JJ. Escalas de valoración del riesgo de desarrollar úlceras por presión en la infancia [Scales for assessing the risk of developing pressure ulcers in childhood]. Gerokomos. 2011;22(1):26-34. Spanish [with English abstract].

31. Molina PG. Adaptación cultural y validación de la escala de valoración de riesgo de desarrollar úlceras por presión en neonatos hospitalizados (Neonatal Skin Risk Assessment Scale) [Cultural Adaptation and Validation of the Risk Assessment Scale to Develop Pressure Ulcers in Hospitalized Neonates (Neonatal Skin Risk Assessment Scale)]. Alicante: Universitat d'Alacant-Universidad de Alicante; 2015. Spanish.

32. Willock J, Baharestani MM, Anthony D. The development of the Glamorgan paediatric pressure ulcer risk assessment scale. J Wound Care. 2009;18(1):17-21.

33. Anthony D, Willock J, Baharestani M. A comparison of Braden Q, Garvin and Glamorgan risk assessment scales in paediatrics. J Tissue Viability. 2010;19(3):98-105.

34. Willock J, Habiballah L, Long D, Palmer K, Anthony D. A comparison of the performance of the Braden Q and the Glamorgan paediatric pressure ulcer risk assessment scales in general and intensive care paediatric and neonatal units. J Tissue Viability. 2016;25(2):119-126.

35. Kottner J, Hauss A, Schlüer AB, Dassen T. Validation and clinical impact of paediatric pressure ulcer risk assessment scales: a systematic review. Int J Nurs Stud. 2013;50(6):807-818.

36. García Fernandez FP. Escalas de valoración del riesgo de desarrollar úlceras por presión. Revisión sistemática con meta-análisis [Scales for Assessing the Risk of Developing Pressure Ulcers. Systematic Review with Meta-analysis]. Jaen: Ciencias de la Salud, Jaen University; 2011. Spanish.

37. Dolack M, Huffines B, Stikes R, Hayes P, Logsdon MC. Updated neonatal skin risk assessment scale (NSRAS). Ky Nurse. 2013;61(4):6.

38. García-Molina P, Balaguer-López E, Torra I Bou JE, Alvarez-Ordiales A, Quesada-Ramos C, Verdú-Soriano J. A prospective, longitudinal study to assess use of continuous and reactive low-pressure mattresses to reduce pressure ulcer incidence in a pediatric intensive care unit. Ostomy Wound Manage. 2012;58(7):32-39. 
39. Guideline Development Group. Pressure ulcers: prevention and management of pressure ulcers. In: National Clinical Guideline Centre. London: National Institute for Health and Care Excellence; 2014.

40. Pasek TA, Geyser A, Sidoni M, et al. Skin care team in the pediatric intensive care unit: a model for excellence. Crit Care Nurse. 2008;28(2):125-135.

41. García-Molina P, Balaguer López E, Quesada Ramos C, Ferrara M. UPP Pediatría y otras heridas [UPP pediatrics and other injuries]. 2013. Available from: http://www.upppediatria.org/escalas-valoracion-delriesgo-evrupp/. Spanish. Accessed March 05, 2017.

42. Pennsylvania Patient Safety Authority. Skin integrity issues associated with pulse oximetry. Patient Saf Advis. 2005;2(2):1-6.

43. García-Molina P, Balaguer-López E, Tormos-Muñoz M, et al. Relación entre el estado nutricional y la presencia de úlceras por presión en niños ingresados en un hospital de tercer nivel [Relationship between nutritional status and the presence of pressure ulcers in children admitted to a third level hospital]. Nutr Hospital. 2012;27 Suppl 1:60-65. Spanish [with English abstract].

44. Lund CH, Osborne JW, Kuller J, Lane AT, Lott JW, Raines DA. Neonatal skin care: clinical outcomes of the AWHONN/NANN evidence-based clinical practice guideline. Association of Women's Health, Obstetric and Neonatal Nurses and the National Association of Neonatal Nurses. J Obstet Gynecol Neonatal Nurs. 2001;30(1): $41-51$.

45. Noonan C, Quigley S, Curley MA. Skin integrity in hospitalized infants and children: a prevalence survey. J Pediatr Nurs. 2006;21(6): 445-453.

46. Galbraith SS, Esterly NB. Lesiones traumáticas y yatrogénicas [Traumatic and iatrogenic injuries]. In: Dermatología Neonatal. 2nd ed. Barcelona: Elsevier España; 2009:99-111. Spanish.

47. Cutrone M, Peruzzetto C. Lesiones iatrogénicas en la piel del recién nacido [Iatrogenic lesions on the skin of the newborn]. Dermatol Pediatr Lat. 2006;4(1):9-18. Spanish [with English abstract].

48. Salcedo S, Ribes C, Moraga F. Recién Nacido: cuidado de la piel [Newborn: skin care]. In: Moraga F, editor. Protocolos de dermatología. 2nd ed. Madrid: Asociación Española de Pediatría; 2007:3. Spanish.

49. Scanlon MC, Harris JM 2nd, Levy F, Sedman A. Evaluation of the agency for healthcare research and quality pediatric quality indicators. Pediatrics. 2008;121(6):e1723-e1731.

50. Sankaranarayanan K, Mondkar JA, Chauhan MM, Mascarenhas BM, Mainkar AR, Salvi RY. Oil massage in neonates: an open randomized controlled study of coconut versus mineral oil. Indian Pediatr. 2005;42(9):877-884.

51. Bookout $\mathrm{K}$. Wound care product primer for the nurse practitioner: part I. J Pediatr Health Care. 2008;22(1):60-63.

52. Conner JM, Soll RF, Edwards WH. Topical ointment for preventing infection in preterm infants. Cochrane Database Syst Rev. 2004;(1):CD001150.

53. Pickens WL, Warner RR, Boissy YL, Boissy RE, Hoath SB. Characterization of vernix caseosa: water content, morphology, and elemental analysis. $J$ Invest Dermatol. 2000;115(5):875-881.

54. Mouser T, Helder D. Skin matters: effectiveness of a non-petrolatum emollient cream in pediatric care. Ostomy Wound Manage. 2006;52(11):18, 20

55. Zambrano Pérez E, Torrelo Fernández A, Zambrano Zambrano A. Dermatitis del pañal [Diaper rash]. In: Moraga F, editor. Protocolos de dermatología. 2nd ed. Madrid: Asociación Española de Pediatría; 2007:137-140. Spanish.

56. Lund $\mathrm{CH}$, Osborne JW. Validity and reliability of the neonatal skin condition score. J Obstet Gynecol Neonatal Nurs. 2004;33(3):320-327.

57. Lund CH. Nursing care. In: Assisted Ventilation of the Neonate. 5th ed. Philadelphia: W.B. Saunders; 2011:126-139.

58. Hogeling M, Fardin SR, Frieden IJ, Wargon O. Forehead pressure necrosis in neonates following continuous positive airway pressure. Pediatr Dermatol. 2012;29(1):45-48.

59. Squires AJ, Hyndman M. Prevention of nasal injuries secondary to NCPAP application in the ELBW infant. Neonatal Netw. 2009;28(1):13-27.
60. Ignacio L, Alfaleh K. A randomized controlled trial to compare heated humidified high-flow nasal cannulae with nasal continuous positive airway pressure postextubation in premature infants. J Clin Neonatol. 2013;2(2):75-77.

61. Collins CL, Barfield C, Horne RS, Davis PG. A comparison of nasal trauma in preterm infants extubated to either heated humidified highflow nasal cannulae or nasal continuous positive airway pressure. Eur J Pediatr. 2014;173(2):181-186.

62. Espinoza C, Pereira N, Benavides J, Rostión CG. Ostomías abdominales en pediatría: Una revisión de la literatura [Abdominal ostomies in pediatrics: a review of the literature]. Rev Ped Elec. 2008;5(3):38-48. Spanish [with English abstract].

63. do Nascimento RM, Ferreira AL, Coutinho AC, Santos Veríssimo RC The frequency of nasal injury in newborns due to the use of continuous positive airway pressure with prongs. Rev Lat Am Enfermagem. 2009;17(4):489-494.

64. Collins CL, Holberton JR, Barfield C, Davis PG. A randomized controlled trial to compare heated humidified high-flow nasal cannulae with nasal continuous positive airway pressure postextubation in premature infants. J Pediatr. 2013;162(5):949-954.e1.

65. Xie LH. Hydrocolloid dressing in preventing nasal trauma secondary to nasal continuous positive airway pressure in preterm infants. World J Emerg Med. 2014;5(3):218-222.

66. Butler CT. Pediatric skin care: guidelines for assessment, prevention, and treatment. Dermatol Nurs. 2007;19(5):471-472, 477-482, 485.

67. Association of Women's Health, Obstetric and Neonatal Nurses (AWHONN). Neonatal skin care: evidence-based clinical practice guideline. 2015. Available from: http://www.infantskincareguidelines. com/. Accessed February 1, 2016.

68. Curley MA, Quigley SM, Lin M. Pressure ulcers in pediatric intensive care: incidence and associated factors. Pediatr Crit Care Med. 2003;4(3):284-290.

69. Baharestani MM. An overview of neonatal and pediatric wound care knowledge and considerations. Ostomy Wound Manage. 2007;53(6):34-36, 38, 40, passim.

70. Mehta NM, Compher C; A.S.P.E.N. Board of Directors. A.S.P.E.N Clinical Guidelines: nutrition support of the critically ill child. JPEN J Parenter Enteral Nutr. 2009;33(3):260-276.

71. Quesada C. Manual de Atención Enfermera de Úlceras por Presión en Pediatría [Manual of Attention Nurse of Pressure Ulcers in Pediatrics]. Barcelona: DAE; 2006. Spanish.

72. Curley MA, Razmus IS, Roberts KE, Wypij D. Predicting pressure ulcer risk in pediatric patients: the Braden Q Scale. Nurs Res. 2003;52(1):22-33.

73. Benati G, Bertone MS, Cereda E, et al. Nutritional treatment in patients with pressure ulcers. Acta Vulnol. 2011;9(3):97-127.

74. Tormos Muñoz A, Montal A, Balaguer E, et al. ¿Reciben intervención nutricional los niños hospitalizados acorde al riesgo de desnutrición? [Do hospitalized children receive nutritional intervention according to the risk of malnutrition?]. Nutrición Hospitalaria. 2012;27:60-65. Spanish.

75. Askin DF. Noninvasive ventilation in the neonate. $J$ Perinat Neonat Nurs. 2007;21(4):349-358; quiz 359-360.

76. Grupo de trabajo de la Guía de Práctica Clínica. Guía para la prevención y el tratamiento en pediatría [Guide for prevention and treatment in pediatrics]. In: Guía de Práctica Clínica para el Cuidado de Personas con Úlceras por Presión o Riesgo de Padecerlas. Valencia: Generalitat Valenciana, Conselleria de Sanitat; 2012:129-146. Spanish.

77. Raurell-Torredà M, Romero-Collado $\mathrm{A}$, Rodríguez-Palma M, et al. Prevención y tratamiento de las lesiones cutáneas asociadas a la ventilación mecánica no invasiva. Recomendaciones de expertos. [Prevention and treatment of skin lesions associated with non-invasive mechanical ventilation. Recommendations of experts]. Enferm Intensiva. 2017;28(1):31-41. Spanish [with English abstract].

78. Aube N, Delaitre C, Jarreau PH. Peau: soins d'hygiéne et techniques de surveillance par voie cutanée en reanimation neonatal [Skin care and transcutaneous monitoring in neonatal intensive care unit]. J Gynecol Obstet Biol Reprod (Paris). 2005;34(1 Suppl):S79-S83. French [with English abstract]. 
79. Muñoz MD, Novillo IC, Díaz EM, González MG, Villanueva PI, Isabel AG. Control pediátrico ambulatorio del niño con gastrostomía y ostomías intestinales [Pediatric ambulatory control of the child with gastrostomy and intestinal ostomies]. Pediatr Integral. 2002;6(10):911-918. Spanish [with English abstract].

80. Lin CW, Wang HZ, Hsieh KS. Pulse oximeter-associated toe injuries in a premature neonate: a case report. Zhonghua Yi Xue Za Zhi (Taipei). Chin Med J. 1999;62(12):914-916.

81. Schultz AA, Goodwin PA, Jesseman C, Toews HG, Lane M, Smith C. Evaluating the effectiveness of gel pillows for reducing bilateral head flattening in preterm infants: a randomized controlled pilot study. Appl Nurs Res. 2008;21(4):191-198.

82. McLane KM, Bookout K, McCord S, McCain J, Jefferson LS. The 2003 national pediatric pressure ulcer and skin breakdown prevalence survey: a multisite study. J Wound Ostomy Continence Nurs. 2004;31(4): $168-178$.

83. García Molina P, Balaguer López E. Superficies Especiales del Manejo dela Presión en pediatría (I). Características y competencia. [Special therapeutic surfaces for handling pressure in pediatrics (I). Characteristics and competency]. Rev Enferm. 2009;32(2):17-24. Spanish [with English abstract].

84. Sánchez-Lorente M, García-Molina P, Vergara-Hernández C, et al. Assessment of suport surfaces (static \& mixed) for neonates. Presented at: 24th Conference of the European Wound Management Association \& X Simposio Nacional sobre Úlceras por Presión y Heridas Crónicas; May 01, 2014; Madrid.

85. Pediatric Affinity Group Working. How-to-guide: pediatric supplement. Preventing Pressure Ulcers. Cambridge: Institute for Health Care Improvement; 2010.

86. Sims A, McDonald R. An overview of paediatric pressure care. JTissue Viability. 2003;13(4):144-146, 148.

87. Rodríguez-Palma M, López Casanova P, García Molina P, Ibars Moncasi P. Superficies especiales para el manejo de la presión en prevención y tratamiento de las úlceras por presión [Special surfaces for the management of pressure in the prevention and treatment of pressure ulcers]. Serie Documentos Técnicos GNEAUPP ${ }^{\circ}$ XIII. Logroño: GNEAUPP; 2011. Spanish.

88. García Molina P, Balaguer López E. Superficies Especiales del Manejo de la Presión en pediatría (II). Elección, algoritmo de asignación (TARISE) y modelos de valoración. [Special surfaces for managing pressure in pediatrics (II). Choice, assigned algorithm (Tarise) and management models]. Rev Enferm. 2009;32(4):14-20. Spanish [with English abstract].

89. Turnage-Carrier C, McLane KM, Gregurich MA. Interface pressure comparison of healthy premature infants with various neonatal bed surfaces. Adv Neonatal Care. 2008;8(3):176-184.

90. García Molina P, Balaguer López E, Jiménez Gómez M. Alivio de la presión con SEMPCARE CARITAL JUVE, sistema de flotación dinámica reactiva a la presión, y SEMPCARE VISCO 700, cojín viscoelástico para la fijación y el alivio local de la presión en la cabeza, en un paciente pediátrico en riesgo extremo de desarrollo de UPP [Pressure relief with SEMPCARE CARITAL JUVE, dynamic pressure-reactive flotation system, and SEMPCARE VISCO 700, viscoelastic cushion for fixation and local pressure relief in the head, in a pediatric patient at extreme risk of developing UPP]. In: Bou Ti JE, editor. Monografia Prevencare 2. Casos Clínicos sobre prevención UPP y lesiones por humedad e incontinencia. Sant Joan Despí: Smith \& Nephew; 2010:60. Spanish.

91. Raeve PD. Two mattresses for neonates compared for costs and quality of nursing care. Connect Crit Care Nurs Eur. 2001;1(1):5-10.

92. Solis I, Krouskop T, Trainer N, Marburger R. Supine interface pressure in children. Arch Phys Med Rehabil. 1988;69(7):524-526.

93. Levy A, Kopplin K, Gefen A. Adjustability and adaptability are critical characteristics of pediatric support surfaces. Adv Wound Care (New Rochelle). 2015;4(10):615-622.
94. Gefen A. Biomechanics of PUs in paediatric care settings. J Wound Care. 2015;24(3):81.

95. García-Molina P, Alonso C, Balaguer-López E. Revisión sobre las recomendaciones de expertos en el Manejo de las Heridas en Pediatría. Parte III. Documentos de revisión sobre heridas en pediatría. 2015. Available from: www.upppediatria.org/wp-content/uploads/ Manejo_heridas_pediatria_III.pdf. Accessed June 20, 2017.

96. Best Practice Statement. Principles of wound management in paediatric patients. In: London: Wounds UK; 2014. Available from: http:// www.wounds-uk.com/best-practice-statements/principles-of-woundmanagement-in-paediatric-patients. Accessed May 20, 2017.

97. Cousins Y. Wound care considerations in neonates. Nurs Stand. 2014;28(46):61-70.

98. Lesher AP, Curry RH, Evans J, et al. Effectiveness of Biobrane for treatment of partial-thickness burns in children. J Pediatr Surg. 2011;46(9):1759-1763.

99. Schindler CA, Mikhailov TA, Fischer K, Lukasiewicz G, Kuhn EM, Duncan L. Skin integrity in critically ill and injured children. Am J Crit Care. 2007;16(6):568-574.

100. Fox MD. Wound care in the neonatal intensive care unit. Neonatal Netw. 2011;30(5):291-303.

101. King A, Stellar JJ, Blevins A, Shah KN. Dressings and products in pediatric wound care. Adv Wound Care (New Rochelle). 2014;3(4): 324-334.

102. Smith ZK. Adapting a soft silicone dressing to enhance infant outcomes. Ostomy Wound Manage. 2006;52(4):30-32.

103. Samaniego I. Developing a skin care pathway for pediatrics. Dermatol Nurs. 2002;14(6):393-396.

104. Lo S, McGoldrick R, Moss AL. Pitfalls in managing pressure sores in children: to debride or not debride? J Plast Reconstr Aesthet Surg. 2010;63(1):e118-e119.

105. Merei JM. Pediatric clean surgical wounds: is dressing necessary? J Pediatr Surg. 2004;39(12):1871-1873.

106. García-Molina P, Balaguer-López E. Manejo de la Piel [Skin management]. In: del Carmen Sellán Soto M, Vázquez Sellán A, editors. Cuidados Neonatales en Enfermería. Madrid: Elsevier; 2017. Spanish.

107. White RJ, Fumarola S, Denyer J. Interim advice on silver dressings in neonatal/paediatric wound and skin care. J Wound Care. 2011; 20(4):192.

108. Kutsch J, Ottinger D. Neonatal skin and chlorhexidine: a burning experience. Neonatal Netw. 2014;33(1):19-23.

109. August DL, Ireland S, Benton J. Silver-based dressing in an extremely low-birth-weight infant: a case study. $J$ Wound Ostomy Continence Nurs. 2015;42(3):290-293.

110. Spray A, Siegfried E. Dermatologic toxicology in children. Pediatr Ann. 2001;30(4):197-202.

111. Letouze A, Voinchet V, Hoecht B, Muenter KC, Vives R, Bohbot S. Using a new lipidocolloid dressing in paediatric wounds: results of French and German clinical studies. J Wound Care. 2004;13(6):221-225.

112. Neilson J, Avital L, Willock J, Broad N. Using a national guideline to prevent and manage pressure ulcers. Nurs Manag (Harrow). 2014;21(2): 18-21.

113. Willock J, Hughes J, Tickle S, Rossiter G, Johnson C, Pye H. Pressure sores in children--the acute hospital perspective. J Tissue Viability. 2000;10(2):59-62.

114. Meszes A, Tálosi G, Máder K, et al. Successful postoperative treatment of a lumbosacral ulcer in a neonate after myelomeningocele. Case Rep Dermatol. 2014;6(1):54-58.

115. Osti E. Cutaneous burns treated with hydrogel (Burnshield) and a semipermeable adhesive film. Arch Surg. 2006;141(1):39-42.

116. Visscher MO. Update on the use of topical agents in neonates. Newborn Infant Nurs Rev. 2009;9(1):31-47.

117. Baharestani M, Amjad I, Bookout K, et al. V.A.C. Therapy in the management of paediatric wounds: clinical review and experience. Int Wound J. 2009;6 Suppl 1:1-26. 
Research and Reports in Neonatology is an international, peer-reviewed, open access journal publishing original research, reports, editorials, reviews and commentaries on neonatal health. The manuscript management system is completely online and includes a very quick and fair peer-review system. Visit http://www.dovepress.com/testimonials.php to read real quotes from published authors.

Submit your manuscript here: https://www.dovepress.com/research-and-reports-in-neonatology-journal 